\title{
COMPUTATIONAL ANALYSIS OF PULVERIZED COAL CO-FIRING WITH BIOMASS IN 150MWE UNIT OF TUNCBILEK THERMAL POWER PLANT
}

\author{
Cansu DENIZ CANAL*, Yakup Erhan BOKE**, Ozer AYDIN*** and Ali Cemal BENIM**** \\ ****Department of Mechanical Engineering, Istanbul Technical University, Istanbul, Turkey \\ *cansudeniz@itu.edu.tr, ORCID: 0000-0001-5564-0919, **boke@itu.edu.tr, ORCID: 0000-0003-0449-0329 \\ ***Department of Mechanical Engineering, Kutahya Dumlupinar University, Kutahya, Turkey \\ ozer.aydin@dpu.edu.tr, ORCID: 0000-0002-6397-5601 \\ $* * * *$ Center of Flow Simulation, Faculty of Mechanical and Process Engineering, \\ Duesseldorf University of Applied Sciences, Germany, \\ alicemal@prof-benim.com, ORCID: 0000-0002-8642-2225
}

(Geliş Tarihi: 15.06.2020, Kabul Tarihi: 28.12.2020)

\begin{abstract}
Pulverized coal and biomass co-firing in the 150MWe unit of Tuncbilek power plant is computationally investigated, within the scope of a preliminary feasibility study. The considered furnace, burning Turkish lignite, has totally eighteen burners, positioned at three different levels. First, the pulverized coal combustion in the furnace is calculated and the predicted temperatures in the boiler first pass are compared with the previous measurements. Subsequently, a co-firing scenario is computationally analyzed, where the burners of the lowest level that supply $43 \%$ of the total fuel mass are fed by biomass, instead of coal. Turkish red pine is assumed to be the source of the biomass. In replacing the coal by biomass, the mass flow rates of the biomass and the corresponding air are adjusted in such a way that the thermal load and the equivalence ratio remain unaltered. Due to the lack of more accurate data for the biomass, the rate constants for the pyrolysis and chemical conversion of biomass are assumed to be the same as those of coal, along with the assumption of the same particle size distribution for both fuels. It is observed that the resulting flame structure for the case of co-firing is very similar to that of coal combustion. This result is encouraging for the application of biomass co-firing in the considered furnace.
\end{abstract}

Keywords: Computational Fluid Dynamics, Pulverized Fuel Combustion, Coal and Biomass Co-firing

\section{TUNCBILEK TERMIK SANTRALININ 150MWe ÜNITESINDE PÜLVERIZE KÖMÜRÜN BIYYOKÜTLE İLE EŞ YANMASININ HESAPLAMALI ANALIZİ}

\begin{abstract}
Özet: Pülverize kömür ve biyokütlenin birlikte yanması Tunçbilek termik santralinin 150MWe kapasitesindeki ünitesi için, bir ön fizibilite çalışması kapsamında, sayısal olarak incelenmiştir. Türk linyit kömürü yakmakta olan söz konusu fırın, üç seviyeye yerleștirilmiş toplam on sekiz brülörden beslenmektedir. İlk olarak, firında pülverize kömür yanması hesaplanmış ve kazan birinci geçis kanalı içinde bulunan sıcaklıklar daha önceki ölçümlerle karşılaştırılmıştır. Akabinde, toplam yakıt kütlesinin \%43‘ünü sağlayan en alt seviyedeki brülörlerden, kömür yerine biyokütle gönderilmesini öngören bir eş yanma senaryosu hesaplamalı olarak analiz edilmiştir. Türk kızıl çamı biyokütle kaynağı olarak kabul edilmiştir. Kömürü, biyokütle yakıtı ile değiş̧irirken, biyokütle ve hava debileri termik güç ve hava fazlalık katsayısının sabit kalacağı şekilde ayarlanmıştır. Her iki yakıt için de aynı partikül büyüklük dağılımı kabul edilirken, elde daha hassas bilgi olmamasından dolayı, biyokütlenin piroliz ve kimyasal dönüşümü ile ilgili hız sabitlerinin, kömür için kullanılanlar ile aynı olduğu kabul edilmiştir. Birlikte yanma durumunda elde edilen alev yapısının kömür yanmasınınkine çok benzer olduğu gözlemlenmiştir. Bu netice, incelenen kazanda biyokütlenin kömür ile birlikte yanmasını teşvik edici niteliktedir.
\end{abstract}

Anahtar Kelimeler: Hesaplamalı Akışkanlar Dinamiği, Pülverize Yakıt Yanması, Kömür ile Biyokütle Birlikte Yanmas

\section{NOMENCLATURE}

A $\quad$ Fuel ash mass fraction [-]

A, $A_{i}$ Pre-exponential factor [case dependent units]

$\mathrm{E}, \mathrm{E}_{\mathrm{i}} \quad$ Activation energy [J/kmol]

FC Fuel fixed carbon mass fraction [-]

$\mathrm{k} \quad$ Turbulence kinetic energy $\left[\mathrm{m}^{2} / \mathrm{s}^{2}\right]$

$\mathrm{k}, \mathrm{k}_{\mathrm{i}}, \mathrm{K}_{\mathrm{i}} \quad$ Reaction rate coefficient [units case dependent]
LHV Lower heating value $[\mathrm{J} / \mathrm{kg}]$

m Mass flow rate $[\mathrm{kg} / \mathrm{s}]$

M Fuel moisture mass fraction [-]

$\mathrm{n}_{\mathrm{j}} \quad$ Rate exponent belonging to species $\mathrm{j}[-]$

$\mathrm{T} \quad$ Gas temperature [K]

HHV Higher heating value $[\mathrm{J} / \mathrm{kg}]$

$\mathrm{V}$ Velocity magnitude $[\mathrm{m} / \mathrm{s}]$

VM Fuel volatile matter mass fraction [-] 


\section{$\mathrm{Xi} \quad$ Mole fraction of species $\mathrm{j}[-]$ \\ $\mathrm{y}^{+} \quad$ Non-dimensional wall distance [-] \\ Greek Symbols}

$\varepsilon \quad$ Dissipation rate of turb. kin. energy $\left[\mathrm{m}^{2} / \mathrm{s}^{3}\right]$

$\omega \quad$ Turbulence frequency $(=\varepsilon / \mathrm{k})[1 / \mathrm{s}]$

\section{Abbreviations}

$\begin{array}{ll}\text { DAF } & \text { Dry and Ash Free substance } \\ \text { EDM } & \text { Eddy Dissipation Model } \\ \text { L } & \text { Lower burner level } \\ \text { M } & \text { Middle burner level } \\ \text { MF } & \text { Mixture fraction } \\ \text { MFR } & \text { Mass fraction in percent } \\ \text { PDF } & \text { Probability Density Function } \\ \text { RANS } & \text { Reynolds Averaged Navier Stokes } \\ \text { U } & \text { Upper burner level }\end{array}$

\section{Subscripts}

$\begin{array}{ll}\text { aver } & \text { Area averaged value } \\ \text { C } & \text { Char, Coal } \\ \text { B } & \text { Biomass } \\ \text { D } & \text { Diffusion } \\ \text { K } & \text { Kinetic } \\ \text { p } & \text { Pyrolysis }\end{array}$

\section{INTRODUCTION}

For the generation of power and heat, combustion is being used as the major process since many decades (Benim et al., 2005, Kim et al., 2007, Benim, 1990, Benim et al. 2017). For solid fuels, gasification techniques are additionally used (Yilmazoglu and Durmaz, 2012, Benim and Kuppa, 2016). In parallel to the efforts of utilizing renewable energies (Ehrlich, 2013), as well as recovery techniques (DuBois and Mercier, 2009, Ebling et al., 2016), combustion continues to play an important role in renewable energies. This is due to the fact that the biomass, which is a renewable fuel, is also converted by combustion (Açikkalp et al., 2018, Kaltschmitt, 2019, Shi et al., 2019, Smith et al., 2019). Thus, the energetic utilization of biomass via combustion process is the main focus of the present contribution.

In large and medium scale utility boilers that are designed to fire pulverized coal, the common way of burning biomass is co-combustion (Kaltschmitt et al., 2016). In utility boilers, usually only a rather small portion of the energy feed $(<50 \%)$ is provided by the biomass. This limited use of biomass is caused, on the one hand, by the different fuel properties of biomass, especially with respect to its ash that can lead to increased corrosion problems (which are not addressed in the present study). On the other hand, the logistic reasons play here a role, as the available biomass in the catchment area of the power plant with affordable transport costs limits the extent of biomass usage.

Co-combustion of biomass in pulverized coal firing utility boilers was investigated by many researchers. One of the early, detailed studies is due to Hein and Spliethoff (1995), who experimentally investigated the co-combustion of biomass in pulverized fuel and fluidized bed systems, which was extended to the investigation of the slagging (Heinzel et al., 1998) and corrosion behaviour (Stephan et al., 2017) in further studies. Nitrogen oxide (NOx) emissions were in the focus of the experimental investigations of Nimmo et al. (2010) and Munir et al. (2011). Co-firing of pulverised coal and biomass in a small-scale furnace with a single burner was computationally investigated by Bhuiyan and Naser (2015a), who also analysed large scale power plants for oxy-fuel combustion (Bhuiyan and Naser, 2015b). Experimental and computational studies of pulverised coal and biomass co-combustion in a large scale furnace was provided by Tamura et al. (2014), which was focussing on the effect of grinding. In a rather recent investigation, Pérez-Jeldres et al. (2017) presented a computational modelling of a large scale pulverized fuel furnace for co-firing of coal and biomass, with emphasis on pollutant emissions.

In Turkey, the lignite is the dominating fossil fuel source. The Turkish lignite is characterised by rather high ash content, and consequently, with rather low calorific values (Atimtay et al., 2017). Pulverized combustion of Turkish lignite was computationally investigated in different applications by various researchers (Aydin and Durak, 2012).

Pulverized combustion of Turkish lignite in the presently considered furnace, i.e. the $150 \mathrm{MWe}$ unit of the Tuncbilek thermal power plant was computationally investigated, previously, by Ozdemir and Boke (2015). In that work, a mixture fraction based presumed PDF (MF-PPDF) approach (Libby and Williams, 1994) was used as the turbulent combustion model for the gas phase reactions, which assumes a purely mixing controlled combustion. In the presently applied Eddy Dissipation Model (EDM) based methodology, the kinetics effects are additionally considered. An additional difference to the work of Ozdemir and Boke (2015) is the analysis of biomass co-firing.

As a future perspective for biomass utilization in the Tuncbilek thermal power plant, it is envisaged to co-fire Turkish forest red pine. The present study can be considered as a preliminary exploration of biomass (Turkish forest red pine tree wood) co-firing capability in the $150 \mathrm{MWe}$ furnace of Tuncbilek thermal power plant, by means of computational modelling.

Compared to the previous work (Ozdemir and Boke, 2015), the novelty of the present work resides mainly in two points. Firstly, the EDM is used as turbulent 
combustion model that explicitly addresses kinetics effects. In the previous work, MF-PPDF model was used, which assumes infinitely fast chemistry in the gas phase. It shall also be noted that the use of the MFPPDF in cases with multiple fuels (like in the present case of biomass co-firing) becomes cumbersome and more prone to inaccuracies, since multiple mixture fractions and their interaction need to be modelled. Secondly, the biomass co-firing is investigated in the present study, while only coal combustion was studied in the previous work.

The above-mentioned preliminary nature of the present study is due to the missing empirical data to characterize the pyrolysis and solid phase oxidation of Turkish forest red pine, which are currently substituted by wellestablished coal data. In case of the availability of such data for Turkish forest red pine, it would be possible to obtain more accurate predictions in the future.

\section{MODELING}

The general-purpose Computational Fluid Dynamics (CFD) code ANSYS Fluent 19.0 R3 (ANSYS Fluent Theory Guide, 2019) is used, which utilizes a finite volume method of discretization. The density of the gas mixture is calculated assuming an ideal gas. The specific heat capacity of the gas mixture is calculated via fourth order polynomials of temperature. Temperature dependence of the molecular transport properties are neglected (Turns, 2012). The SIMPLE algorithm is used to treat the velocity-pressure coupling. The second-order upwind scheme is utilized to discretize the convection terms. The gradient computation technique was least squares cell based. Stabilization was achieved by a standard cell to face slope limiter. For convergence, it was required that the scaled residuals of all balance equations except the energy and radiation transport equation are smaller than $10^{-3}$. For the energy and the radiation transport equations, the required threshold value was $10^{-6}$.

\section{Two-Phase Flow and Convective Transport}

For the modelling of the two-phase flow, it has previously been shown that an Eulerian-Eulerian formulation offers computational advantages over the Eulerian-Lagrangian formulation, in the modelling of utility boilers (Benim et al., 2005). Still, in the present work, an Eulerian-Lagrangian approach is adopted, as it is the built-in standard formulation of the employed software, for pulverized coal combustion. The gas phase and particle phase equations are solved alternately, where, the particle iterations are performed after each $30^{\text {th }}$ gaseous phase iteration.

The volume occupied by particles, and particle-particle interactions are neglected. Only the gravity and drag force on particle are considered, assuming a spherical shape for the latter (Morsi and Alexander, 2006). The size distribution is assumed to follow the RosinRammler distribution (Lefebvre and McDonnel, 2017).

A uniform particle temperature is assumed calculating the convective heat transfer coefficient using the correlation of Ranz and Marshall (1952).

\section{Turbulence}

The Reynolds Averaged Navier Stokes (RANS) approach is used to model the turbulent gas flow, where using a turbulent viscosity based turbulence model. Although $\omega$-based turbulence models (k- $\omega$, SST) became popular in recent years (Menter, 1994), which are especially suitable for wall-driven turbulent flows (Bhattacharyya et al., 2017), in the present case that is governed by free shear layers, turbulence is described by the Standard k- $\varepsilon$ model, amended by the standard wallfunctions for the near-wall turbulence (Launder and Spalding, 1974). For the turbulent diffusion of the scalar quantities, the gradient-diffusion approximation is used assuming constant Prandtl-Schmidt numbers for the prevailing fully developed turbulent flow $(0.9$ for the energy, 0.7 for the species transport equations). The effect of gas turbulence on the particle motion is modelled by the so-called "discrete random walk" model (Gosman and Ioannides, 1983), whereas the influence of the particle phase on the gas turbulence is neglected.

\section{Radiative Heat Transfer}

The radiative heat transfer is modelled by the $\mathrm{P} 1$ model (Benim, 1988). The absorption coefficient of the gas mixture is calculated using the Weighted Sum of Gray Gases Model (WSGGM) (Smith et al. 1982), assuming an equivalent path length for the domain. The particle phase radiation is taken into account assuming the value of 0.9 for particle emissivity and scattering factor. The walls are assumed to reflect diffusely. The wall emissivity is assumed to be 0.9 .

\section{Combustion Modelling}

The solid fuel particle experiences an evaporation and pyrolysis with increasing particle temperature. The residual char burns via heterogeneous reactions, as the combustible volatile matter reacts homogeneously in the gas phase.

Please note that small amounts of Sulphur and Nitrogen contained in the fuel are also allowed to react to $\mathrm{SO}_{2}$ and $\mathrm{NO}_{2}$, respectively, assuming single-step global reactions. However, this is done for the sake of consistency, without paying special attention to an accurate modelling of the reaction rates (as these reactions do not remarkably affect the velocity, temperature and main species concentrations). Therefore, these reactions will not additionally be referred to in the following. The assumed reactions and combustion models are outlined in more detail below: 
Pyrolysis

During the pyrolysis, the swelling of the particles is accounted for, with an assumed swelling coefficient of 1.4. The combustible volatile matter is represented by a molecule $\mathrm{C}_{\mathrm{x}} \mathrm{H}_{\mathrm{y}} \mathrm{O}_{\mathrm{z}}$, assuming a molar mass of 30 $\mathrm{kg} / \mathrm{kmol}$, where $\mathrm{x}, \mathrm{y}, \mathrm{z}$ depend on the elementary analysis of the fuel.

Following Badzioch and Hawskley (1970), a first-order, single-rate pyrolysis is assumed, where the rate coefficient is expressed by an Arrhenius rate expression. For the rate constants, the commonly used values for lignite are employed (Epple, et al. 2012) that are listed in Table 1.

Table 1. Pyrolysis model rate constants.

\begin{tabular}{|c|c|}
\hline $\mathrm{A}_{\mathrm{p}}$ & $\mathrm{E}_{\mathrm{p}}$ \\
\hline $3.82 \cdot 10^{5}$ & $74 \cdot 10^{6}$ \\
\hline
\end{tabular}

Pyrolysis kinetics of biomass (Neves et al., 2011) is, however, not well established. Due to the lack of data for the currently envisaged biomass, i.e. the Turkish red pine, the same pyrolysis rate coefficients as the coal (Table 1) are used for the biomass, too. This potential source of uncertainty is to be reduced in future studies trying to incorporate more specific data.

\section{Char oxidation}

Char is assumed to oxidize to carbon monoxide in a single-step irreversible heterogeneous surface reaction. The rate coefficient is calculated considering a combined rate limiting effects of kinetic and diffusion processes (Field et al., 1967, Baum and Street, 1971). The kinetic rate is described by an Arrhenius ate expression. The diffusion rate is calculated as function of particle size, boundary layer temperature and diffusion coefficient. The used model rate constants are presented in Table 2 (Field et al., 1967, Baum and Street, 1971).

Table 2. Char oxidation model rate constants.

\begin{tabular}{|c|c|c|}
\hline $\mathrm{A}_{\mathrm{K}}$ & $\mathrm{E}_{\mathrm{K}}$ & $\mathrm{K}_{\mathrm{D}}$ \\
\hline $2.10^{-5}$ & $79.4 \cdot 10^{6}$ & $5.0 \cdot 10^{-12}$ \\
\hline
\end{tabular}

It is considered that the released heat by combustion is partially absorbed by the particle itself. In the current study, heat of reaction absorbed by the particle is assumed to be $30 \%$ in ratio.

Gas phase reactions

The combustion in the gas phase is assumed to occur via a global reaction scheme comprising two irreversible reactions (Turns, 2012). In the first reaction, the volatile matter is assumed to react to $\mathrm{CO}$ and $\mathrm{H}_{2} \mathrm{O}$. The second reaction is the oxidation of $\mathrm{CO}$ to $\mathrm{CO}_{2}$.

As the rate constants for the chemical kinetics, the default values suggested by the used software have been used, which are displayed in Table 3. They represent a modified set of the empirical constants suggested by Dryer and Glassmann (1973) and Westbrook and Dryer (1981) for two-step oxidation of hydrocarbons.

It should be admitted that the rate constants for the first reaction (Table 3) are rather arbitrary, since the assumed, hypothetical volatile molecule structure as $\mathrm{C}_{\mathrm{x}} \mathrm{H}_{\mathrm{y}} \mathrm{O}_{\mathrm{z}}$ is not necessarily corresponding to the hydrocarbons underlying the empirical constants.

Table 3. Kinetic rate constants for gas phase reactions.

\begin{tabular}{|c|c|c|c|c|}
\hline \multirow{2}{*}{$1^{\text {st }}$} & $\mathrm{A}$ & $\mathrm{E}$ & $\mathrm{n}_{\mathrm{CxHyOz}}$ & $\mathrm{n}_{\mathrm{O} 2}$ \\
\cline { 2 - 5 } reaction & $2.119 \cdot 10^{11}$ & $2.027 \cdot 10^{8}$ & 0.2 & 1.3 \\
\hline $2^{\text {nd }}$ & $\mathrm{A}$ & $\mathrm{E}$ & $\mathrm{n}_{\mathrm{CO}}$ & $\mathrm{n}_{\mathrm{O} 2}$ \\
\cline { 2 - 5 } reaction & $2.239 \cdot 10^{12}$ & $1.7 \cdot 10^{8}$ & 1 & 0.25 \\
\hline
\end{tabular}

Nevertheless, it is currently assumed to be a reasonable assumption to take the chemical kinetics effects on the reaction at least approximately into account, in the absence of more accurate information. The same rate constants are used for the oxidation of the volatile matter from coal and biomass.

The effect of turbulence is considered by a rather simple approach. The resultant time-averaged volumetric species conversion rate is assumed to be limited by the smaller one of the kinetic and mixing rates.

The mixing rate, i.e. the rate of mass transfer to smallest scales via dissipation of turbulence eddies, is modelled by the Eddy Dissipation Model (EDM) of Magnussen and Hjertager (1976). The original model constants (Magnussen and Hjertager, 1976) are used.

A brief summary of the applied mathematical and numerical modelling is provided in Table 4.

Table 4. A brief overview of the modelling.

\begin{tabular}{|c|c|}
\hline Two-Phase flow & Eulerian-Lagrangian formulation \\
\hline Turbulence & RANS, Standard k- $\varepsilon$ model \\
\hline Radiation & P1 model \\
\hline Pyrolysis & Single-step scheme \\
\hline Char oxidation & Kinetics and diffusion controlled \\
\hline Gas combustion & 2 step mechanism, EDM \\
\hline Pressure correction & SIMPLE \\
\hline Upwinding & Second order upwind \\
\hline
\end{tabular}

\section{THE FURNACE UNDER CONSIDERATION}

Figure 1 provides a sketch of the longitudinal section of the considered furnace (Aydin, 2013), with a nominal power of $150 \mathrm{MWe}$, of the Tuncbilek thermal power plant.

The boiler top wall is at an elevation of approx. $80 \mathrm{~m}$ from the ground. The burners, which are 18 in total, are placed at three elevations. They are indicated by arrows and the given labels $\mathrm{L}$ (lower), $\mathrm{M}$ (middle), and $\mathrm{U}$ (upper) in the figure. 
In a previous study (Ozdemir and Boke, 2015), flue gas temperature measurements were performed at six stations along the boiler first pass. The positions of these stations are also indicated by arrows and the labels S1S6 in Figure 1. Measured from the position of the upper burner level (U), the elevations of the stations S1- S6 are $13.515 \mathrm{~m}, 19.015 \mathrm{~m}, 22.465 \mathrm{~m}, 28.025 \mathrm{~m}, 30.115 \mathrm{~m}$ and $32.965 \mathrm{~m}$, respectively.

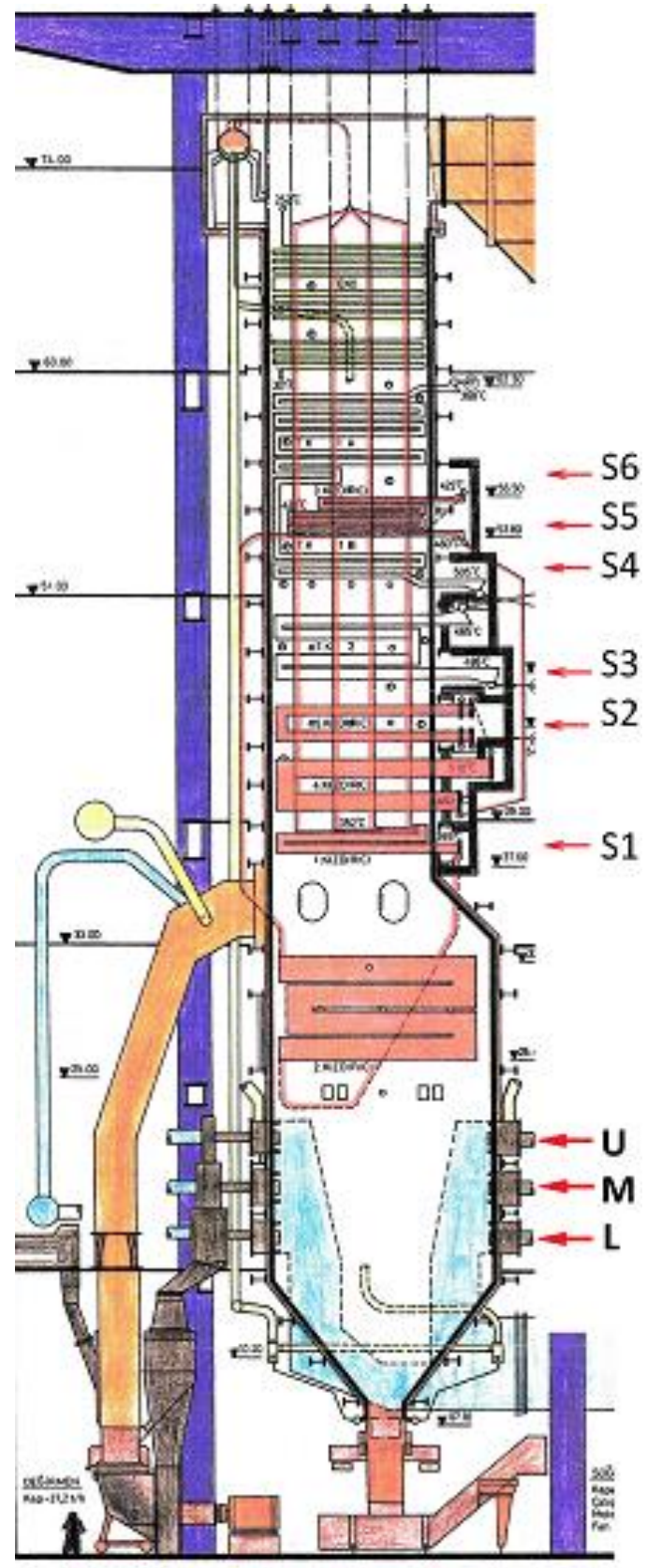

Figure 1. Sketch of longitudinal section of furnace (Aydin, 2013), with indication of burners and measuring stations.

The burner arrangement at a level is basically that of a tangential firing, with four corner and two additional frontal burner groups. The burner configuration at a level is depicted in Figure 2 (Ozdemir and Boke, 2015). As can be seen in Figure 2, the frontal burner pair (on the upper and lower walls, referring to Figure 2) is positioned in a slightly inclined and staggered manner to support the swirling motion generated by the corner burners.

The mass flow rates $(\mathrm{m})$ and temperatures $(\mathrm{T})$ of the coal as well as primary and secondary air feeds to the furnace are presented in Table 5. The prescribed mass flow rates (Table 5) of coal and total air imply an overall excess air ratio of about 1.25.

Table 5. Coal and air feed conditions.

\begin{tabular}{|c|c|c|c|c|c|}
\hline \multicolumn{2}{|c|}{ Coal } & \multicolumn{2}{c|}{ Primary Air } & \multicolumn{2}{c|}{ Secondary Air } \\
\hline $\mathrm{m}$ & $\mathrm{T}$ & $\mathrm{m}$ & $\mathrm{T}$ & $\mathrm{m}$ & $\mathrm{T}$ \\
\hline 38.6 & 573 & 130.7 & 573 & 69.1 & 613 \\
\hline
\end{tabular}

The total coal and total air streams are unevenly distributed among the three burner levels. The percentage distribution of the total coal and air streams among the three burner elevations are presented in Table 6 .

Table 6. Distribution of coal and air mass flow rates among burner levels.

\begin{tabular}{|c|c|c|}
\hline Burner Level & Coal & Air \\
\hline $\mathrm{U}$ & $22 \%$ & $14 \%$ \\
\hline $\mathrm{M}$ & $35 \%$ & $43 \%$ \\
\hline $\mathrm{L}$ & $43 \%$ & $43 \%$ \\
\hline
\end{tabular}

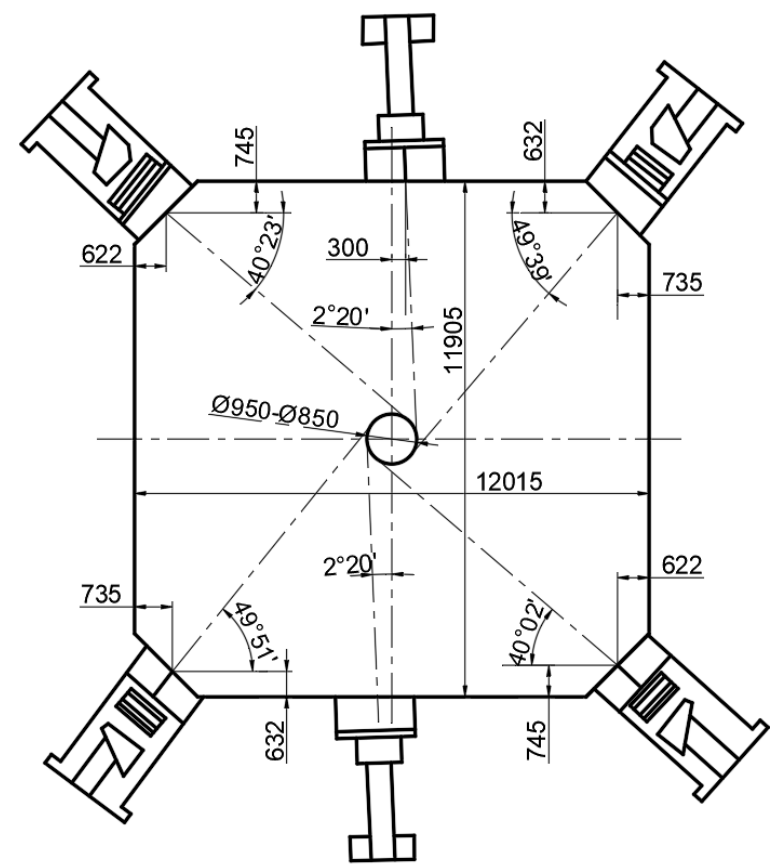

Figure 2. Burner arrangement (Ozdemir and Boke, 2015).

At a given burner level, the corresponding, primary and secondary air mass flow rates are equally distributed among the six burners of the level. The coal mass flow rate is equally distributed among five burners, excluding one corner burner, since one of the corner burners were not firing for the considered furnace operation.

The properties of the Turkish lignite used in the regular operation of the boiler are summarized in Table 7 . 
Table 7. Properties of the used coal (Ozdemir and Boke, 2015).

\begin{tabular}{|c|c|c|c|}
\hline \multicolumn{2}{|c|}{ Proximate Analysis } & \multicolumn{2}{c|}{ Ultimate Analysis (DAF) } \\
\hline Substance & MFR (\%) & Element & MFR (\%) \\
\hline VM & 28.4 & C & 72 \\
\hline FC & 20.4 & H & 5 \\
\hline A & 40.2 & O & 16.2 \\
\hline M & 15.6 & N & 2.7 \\
\hline \multicolumn{2}{|c|}{} & S & 4.1 \\
\hline HHV / LHV & $1.2852 \cdot 10^{7} / 1 \cdot 1960 \cdot 10^{7}$ \\
\hline
\end{tabular}

\section{ASSUMED BIOMASS CO-FIRING CONDITIONS}

For biomass co-firing, it is envisaged to utilize Turkish red pine chips. The properties of the Turkish red pine chips have been borrowed from the study of Atimtay et al. (2017). The presently adopted set of properties is displayed in Table 8.

In Tables 7 and 8, the heating values are obtained from the corresponding chemical composition according to the ultimate analysis of the solid fuel (coal or biomass) applying the relationships provided by Epple et al. (2012).

Comparing both fuels, major differences can be observed in their contents of ash and volatile matter. The present lignite coal has a strikingly high ash content (Table 7), which leads to a comparably low heating value. One can also observe that the red pine chips has a much higher content on the volatile matter (Table 8), compared to coal, which is rather typical for biomass fuels.

Table 8. The assumed properties of the Turkish red pine chips (Atimtay et al. 2017).

\begin{tabular}{|c|c|c|c|}
\hline \multicolumn{2}{|c|}{ Proximate Analysis } & \multicolumn{2}{|c|}{ Ultimate Analysis (DAF) } \\
\hline Substance & MFR (\%) & Element & $\operatorname{MFR}(\%)$ \\
\hline VM & 65.27 & $\mathrm{C}$ & 57.34 \\
\hline $\mathrm{FC}$ & 16.16 & $\mathrm{H}$ & 9.07 \\
\hline $\mathrm{A}$ & 1.56 & $\mathrm{O}$ & 33.35 \\
\hline $\mathrm{M}$ & 17.01 & $\mathrm{~N}$ & 0.24 \\
\hline & & $\mathrm{S}$ & 0 \\
\hline \multicolumn{2}{|c|}{ HHV / LHV } & \multicolumn{2}{|c|}{$2.1512 \cdot 10^{7} / 1 \cdot 9415 \cdot 10^{7}$} \\
\hline
\end{tabular}

In biomass co-firing, in general, a full replacement of coal by biomass is hardly found for large scale utility boilers. A reason is simply the limited availability of the necessary biomass in the catchment area of the power plant.

A further important reason is the increasing potential of hazardous effects (such as high temperature corrosion), depending of the properties of biomass in hand. A replacement by $10-20 \%$ is rather frequently encountered in large scale utility boilers (Kaltschmitt, 2019).

In the present, preliminary feasibility study, it is assumed that the lower level burners (L, Figure 1), which, in total, provide $43 \%$ (Table 6) of the total fuel supply are completely fired by biomass. This choice of the lower burner level for the biomass co-firing is also in line with the suggestion of Tamura et al. (2014).

Thus, the case of biomass co-firing differs from the coal combustion in the mass flow rates of fuel and air at the lower level of burners. The mass flow rate of the biomass is adjusted in such a way that the thermal load compared to coal remains unchanged, i.e.

$\mathrm{m}_{\mathrm{B}}=\mathrm{m}_{\mathrm{C}} \mathrm{LHV}_{\mathrm{C}} / \mathrm{LHV}_{\mathrm{B}}$

The ratio of the LHV is about 0.62 , leading to a biomass flow rate, which is $62 \%$ of the coal mass flow rate of the burner (L). The air supply is adjusted to keep the burner (L) equivalence ratio unchanged between the coal and biomass co-firing cases. The stoichiometric air requirement of biomass is larger compared to coal, due to its larger content on combustibles. The current stoichiometric air requirement ratio of biomass to coal is about 1.61. This means that the burner (L) air mass flow rate for the biomass remains practically unchanged $(0.61$ x 1.61 = approx. 1 ).

\section{GEOMETRY, BOUNDARY CONDITIONS, GRID}

The modelled geometry of the furnace is illustrated in Figure 3. As it can be seen in Figure 1, the upper parts of the furnace are frequently obstructed by heat exchanger tube bundles. These tubes were not resolved in generating the geometry. The increased flow resistance in these regions are approximately modelled by defining this region as a porous media, with a porosity of 0.8 .

The solution domain is enclosed by three types of boundaries: inlet, outlet and walls. The inlet boundaries are attached to the burners (Figure 3c). The outlet boundary is placed at the entry to the second pass of the furnace, which is represented by the gray rectangular zone at the top of the furnace geometry (Figure 3a).

The remaining boundaries are walls. At walls, the noslip boundary condition applies for the momentum equations, which are amended with the wall-functions approach (Launder and Spalding, 1974) for treating the near-wall turbulence. The wall temperature is prescribed to be $659 \mathrm{~K}$, which is $50 \mathrm{~K}$ above the saturation temperature of the water in the pipes. Wall emissivities are assumed to be 0.9 .

At the outlet a constant gauge pressure is prescribed. The outlet is assumed to be black for thermal radiation.

There are two types of inlet boundaries, one for the supply of pulverized fuel and the primary air, and one for the secondary air. The configuration of these boundaries for a burner is illustrated in Figure 3c. On the rectangular inlet surface of a burner, there are four sub-rectangles representing the inlet boundaries for the pulverized fuel and primary air. The remaining area is the inlet boundary for the secondary air. 


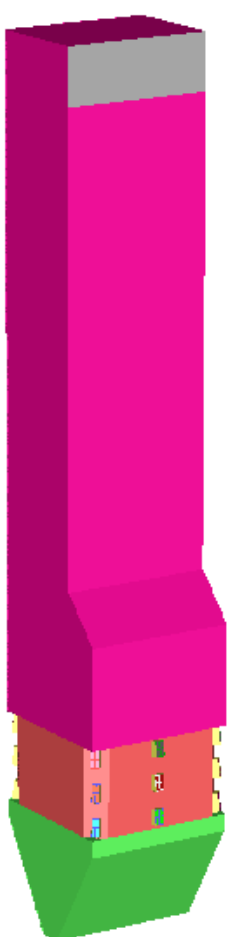

(a)

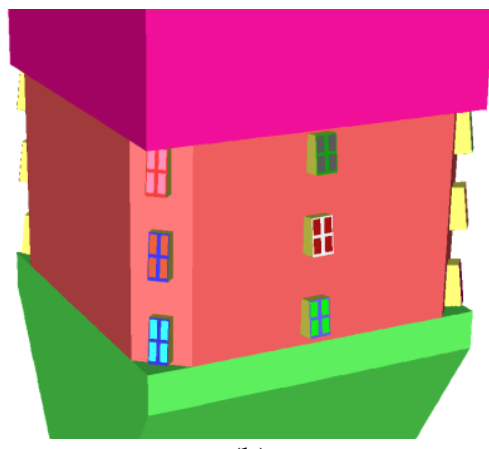

(b)

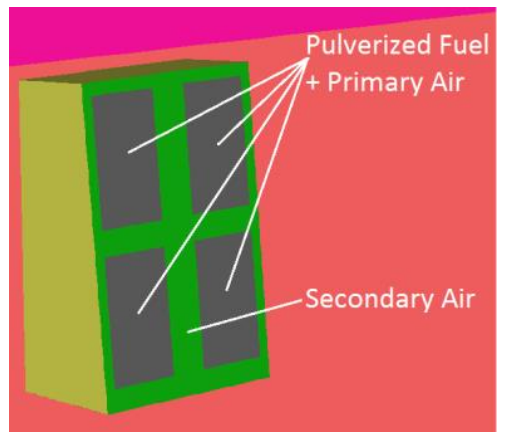

(c)
Figure 3. Geometry, (a) a full view, (b) detail view of the burner belt, (c) detail of a single burner.

At inlets mass flow rates and temperatures for air and coal are prescribed in accordance with the furnace operating conditions as summarized in the previous section, in Tables 5 and 6 . The inlet boundary conditions for the turbulence quantities are estimated based on the prevailing hydraulic diameter and an assumed turbulence intensity of $10 \%$. Inlet boundaries are assumed to behave as black surfaces for thermal radiation.

Depending on the particle size analysis, particle diameters of $90 \mu \mathrm{m}, 500 \mu \mathrm{m}, 100 \mu \mathrm{m}$ are prescribed as the minimum, maximum and mean diameters for the assumed Rosin-Rammler distribution, along with a spread parameter of 4.2 (Lefebvre and McDonnel, 2017). At inlets, the particle velocities are assumed to be equal to the local gas velocity. In experimental trials, it was observed that the pulverization of the used biomass seem to lead to similar results to coal. Thus, for the case of biomass, the same size distribution is applied.

The grid is generated by an unstructured gridding strategy, applying a fine resolution especially in the vicinity of the burners. A detail view of the surface grid in the region of the burner belt is displayed in Figure 4.

The grid has 4.2 million cells in total (base grid). The maximum and average skewness in the grid were 0.85 and 0.29 , respectively. The resulting $\mathrm{y}^{+}$value of the next-to-wall cells was about 550 on the average, which can be considered to be quite adequate for the present free shear-layer dominated turbulent flow, as already pointed out above. A formal grid independence study was not performed. However, the inspection of the recent literature shows that the total number of cells used in discretizing similar furnaces is not necessarily larger than the present one. For example, Madjeski (2018) simulated a 500Wth pulverized furnace with eighteen frontal burners and used a grid with 3 million cells. This may be seen to support the adequacy of the presently used grid. For a further confirmation of the present grid, results are also obtained on a finer grid with 7.3 million cells, for the case of coal combustion.

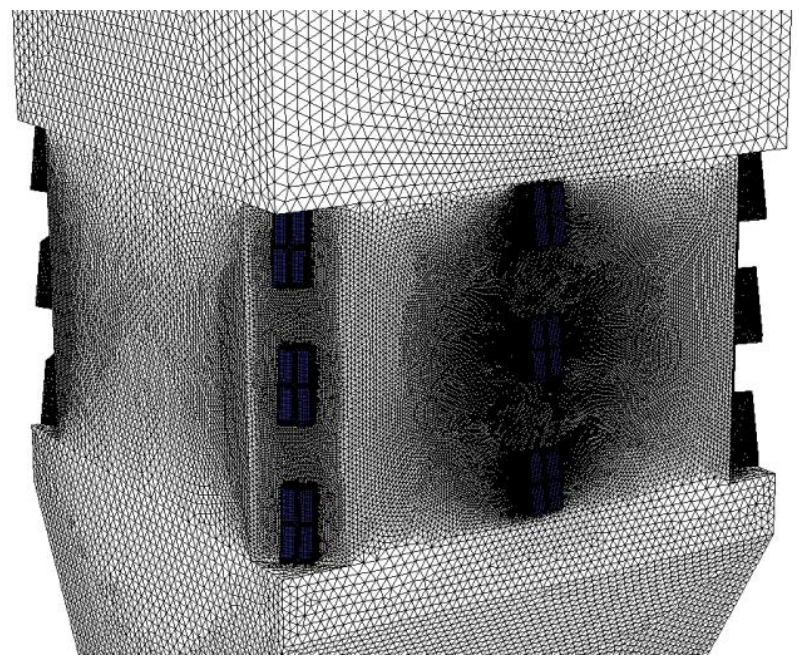

Figure 4. Detail view of surface grid.

\section{RESULTS}

Please note that all results presented in this section are obtained on the grid with 4.2 million cells (base grid), unless otherwise stated explicitly. The above mentioned finer grid with 7.3 million cells is used for comparison, only for the predicted temperatures along the boiler first pass, discussed at the end of the Coal Combustion subsection.

\section{Coal Combustion}

For the pulverized coal combustion, the predicted distributions of velocity vectors at the three burner levels (L, M, U, Figure 1) are displayed in Figures 5a-c (coloring with the velocity vector magnitude). The rotational motion, which is typical for tangentially fired furnaces can be recognized. Due to the difference in the mass flow rates (Table 6) the jets in the levels $\mathrm{L}$ and $\mathrm{M}$ have higher velocities and penetration compared to those at the level $\mathrm{U}$.

The predicted temperature fields at three burner levels are presented in Figures 5d-f. At the low and middle burner levels (L, M) with rather high burner speeds, one can observe that the high-temperature zone is concentrated rather in the middle parts of the furnace. At the upper burner level (U) with comparably low burner velocities, one can see that the temperature distribution is more homogeneous. 
Velocity magnitude and static temperature distributions in the furnace, in a middle, longitudinal plane through the frontal burners are presented in Figure 6.

Comparably higher velocities and penetration of the jets of the $\mathrm{L}$ and $\mathrm{M}$ burner levels compared to the $\mathrm{U}$ level can again be observed (Figure 6a). High temperatures are predicted in the furnace region, which gradually diminish along the boiler first pass due to heat loss to furnace walls (Figure 6b).

The predicted temperatures (PRED) at the stations S1S6 (Figure 1) are compared with the measurements in Figure 7.

In the figure, the predicted temperature values by the finer grid with 7.3 million cells (PRED Finer Grid) are also displayed. The previous predictions of Ozdemir and Boke (2015) using a different combustion model (MFPPDF) are also shown in the figure.

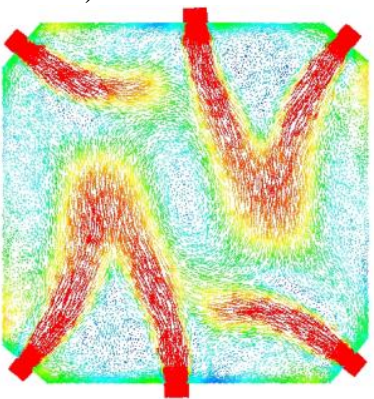

(a)

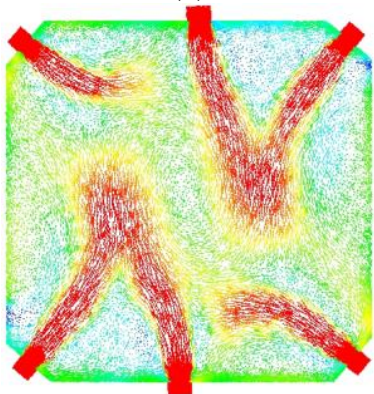

(b)

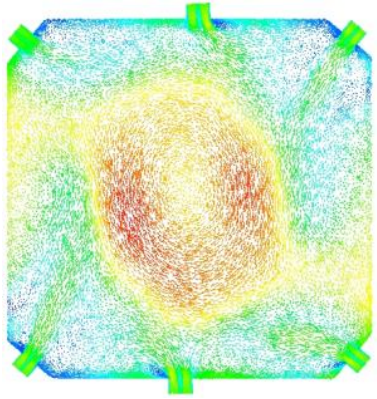

(c)

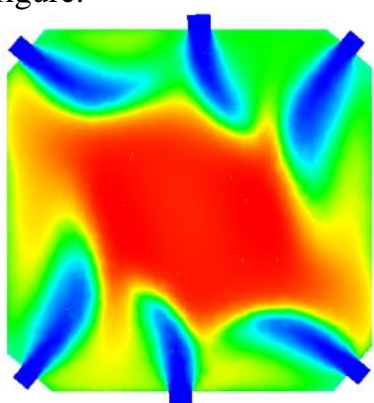

(d)

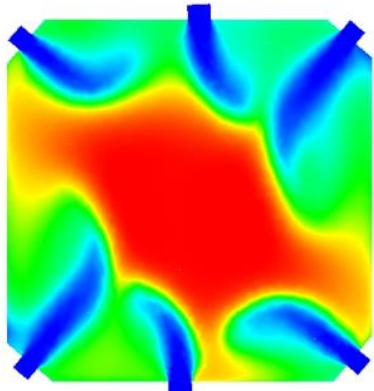

(e)

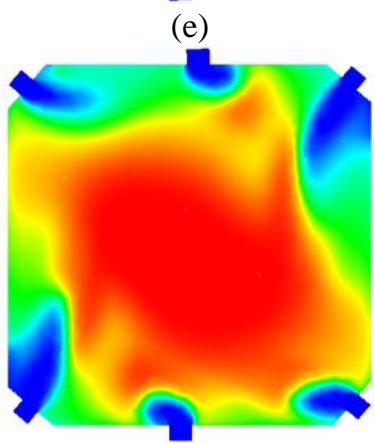

(f)

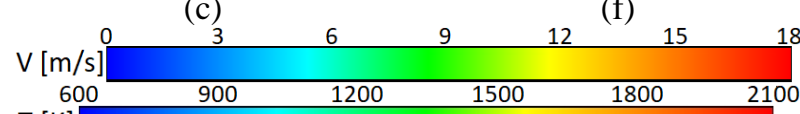

$\mathrm{T}[\mathrm{K}]$

Figure 5. Coal combustion - Predicted fields at three burner levels, velocity vectors: (a) L, (b) M, (c) U, static temperature: (d) L, (e) M, (f) U.

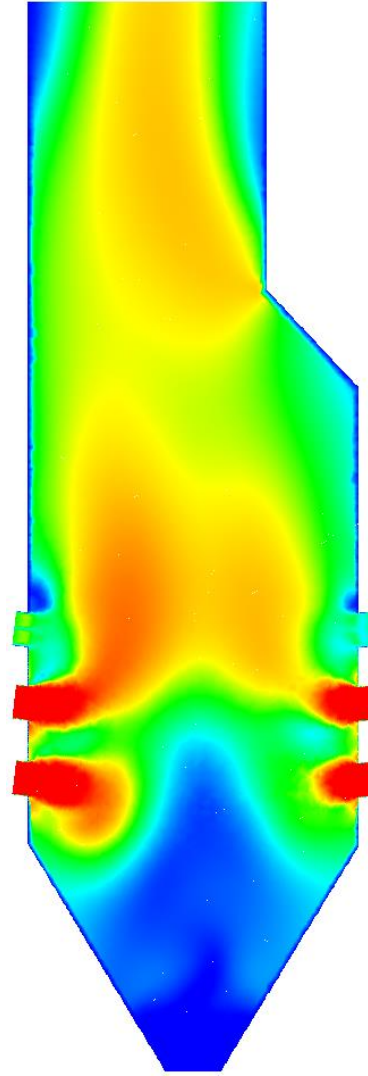

(a)

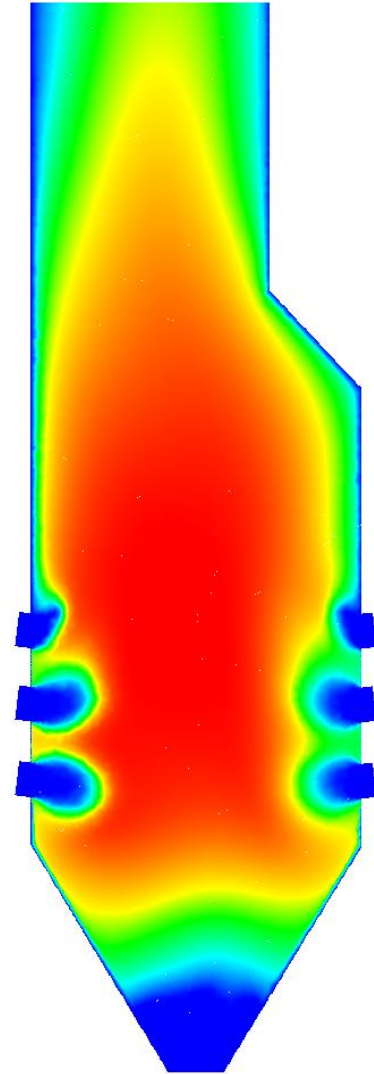

(b)

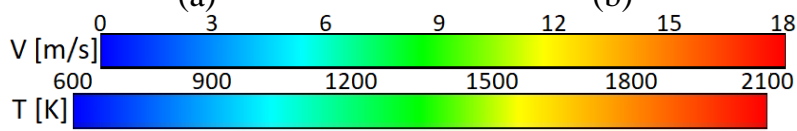

Figure 6. Coal combustion - Predicted fields in the furnace in the longitudinal middle plane through the frontal burners, (a) velocity magnitude, (b) static temperature.

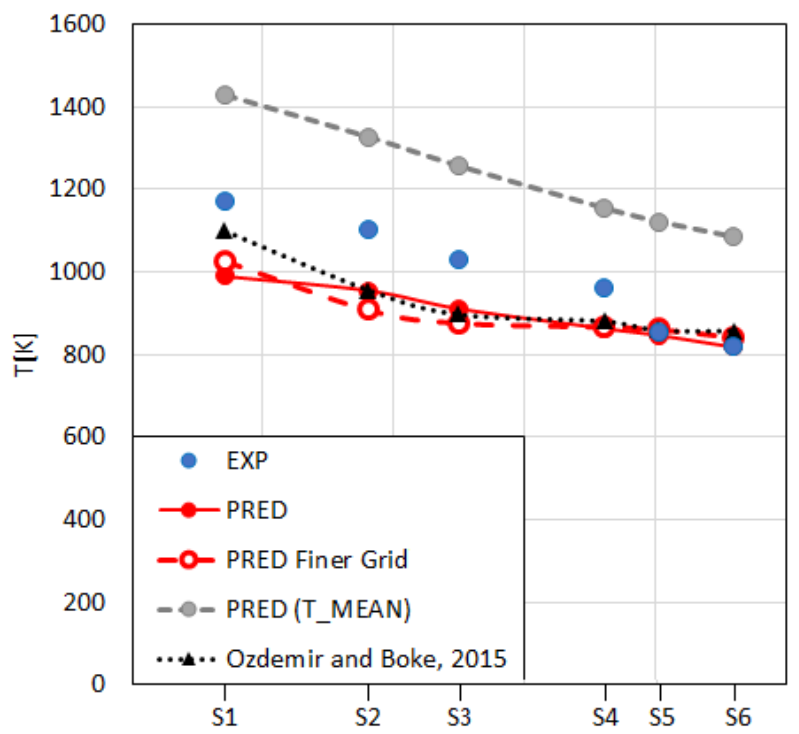

Figure 7. Coal combustion - Measured and predicted temperatures at stations S1-S6 (Figure 1) along the boiler first pass.

At this stage, the performed measurements need to be explained in more detail. The temperature measurements were performed along horizontal lines that are running parallel to furnace walls with a $45 \mathrm{~cm}$ distance to the wall. 
Such measurements were performed only for the two walls without frontal burner (the left and right walls, referring to Figure 2).

Thus, at a given station, there are two lines, where temperature was measured as described above. Along each line, the temperature is averaged. For each station, the average temperatures of the both corresponding lines are again averaged. The displayed experimental and predicted temperatures (EXP, PRED, PRED Finer Grid, Ozdemir and Boke, 2015, Figure 7) are obtained in this manner.

One should note that the significance of these temperatures may be seen to be disputable to an extent, since, being obtained on lines quite near the wall, they may not necessarily be seen to be very representative.

Thus, as complementary information, the predicted average temperatures (mass weighted averaging) at the corresponding cross sections along the boiler first pass are also displayed in the figure (T_MEAN, Fig. 7).

In Figure 7, one can see that for the lines where temperature was measured, the results generally underpredict the measurements, but agree well with the latter for the last two station. One can also see that the cross-sectional mean temperatures are much higher, compared to the line-averaged temperatures. Since the latter are rather close to the relatively cold walls, this is an expected behavior.

At this stage, it should also be noted that the heat transfer (heat extraction) through the heat exchanger tube bundles, which are positioned along the boiler first pass (Figure 1) has not been modelled (although their aerodynamic influence was modelled by assuming a porous media, as indicated above), which can be seen as an argument to explain observed the over-prediction by the mean temperatures.

Although the comparison is not very conclusive, one can still note that the predicted temperatures show a similar general trend to the measurements (Figure 7)

In Figure 7, one can also observe that the results of the finer grid (7.3 million cells) are rather close to those of the base grid supporting the assumption of an adequate grid resolution by the base grid (4.2 million cells), which is also used in the simulation of biomass cofiring, discussed in the following sub-section.

It can also be observed in Figure 7 that the temperatures predicted previously by Ozdemir and Boke (2015) using a different combustion model (MF-PPDF) are very close to the present predictions. This can be seen as a further verification of the present results. At the first station, S1, the predicted value of Ozdemir and Boke (2015) is closer to the experimental value. However, since the measurements are very local along lines close to wall and, therefore, have a disputable representativeness, this shall not necessarily be taken as an indication of a possible superiority of the MF-PPDF model. As already mentioned above, the EDM principally provides a more convenient and flexible framework for modelling the cofiring of different types of fuels and considering chemical kinetics effects.

\section{Biomass Co-firing}

For the co-firing case, the predicted distributions of the velocity vector fields at the three burner levels ( $\mathrm{L}, \mathrm{M}, \mathrm{U}$, Figure 1) are displayed in Figures $8 \mathrm{a}-\mathrm{c}$, while the predicted static temperature fields at the three burner levels are shown in Figures 8d-f. One can see that both the velocity vector field and temperature patterns obtained for the biomass co-firing (Figure 8 ) are very similar to those obtained for the coal combustion (Figure 5).

Distributions of the velocity magnitude as well as the static temperature in the furnace region, in a middle, longitudinal plane through the frontal burners are presented in Figure 9.

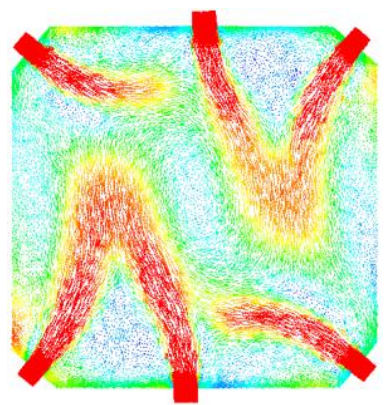

(a)

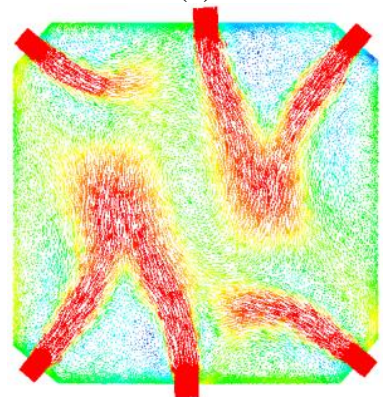

(b)

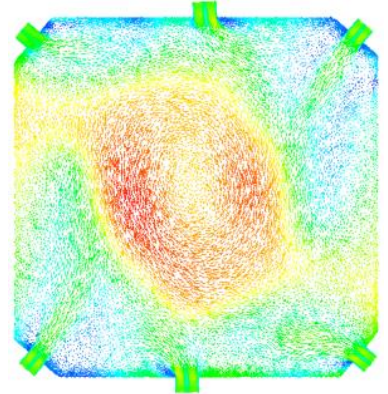

(c)

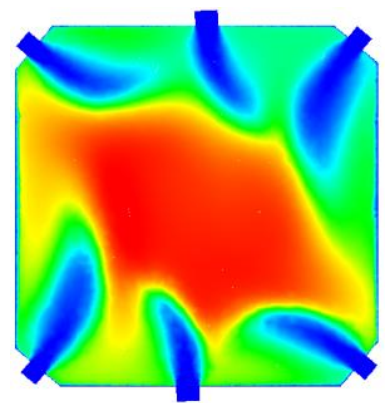

(d)

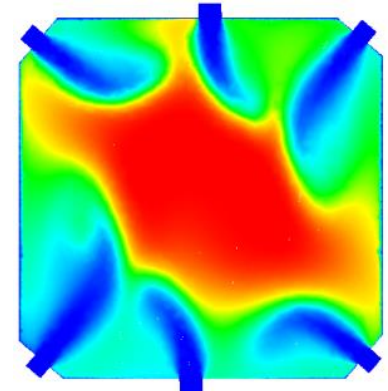

(e)

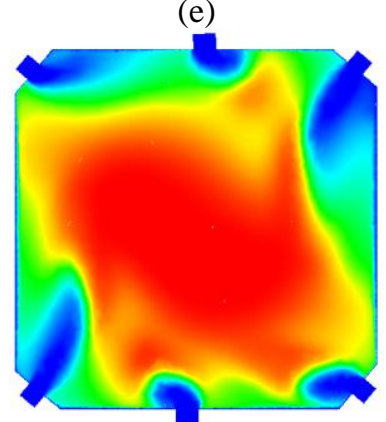

(f)

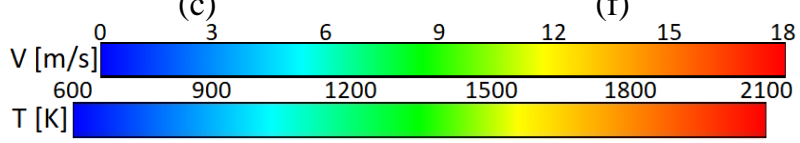

Figure 8. Biomass co-firing - Predicted fields at three burner levels, velocity vectors: (a) L, (b) M, (c) U, static temperature: (d) L, (e) M, (f) U. 


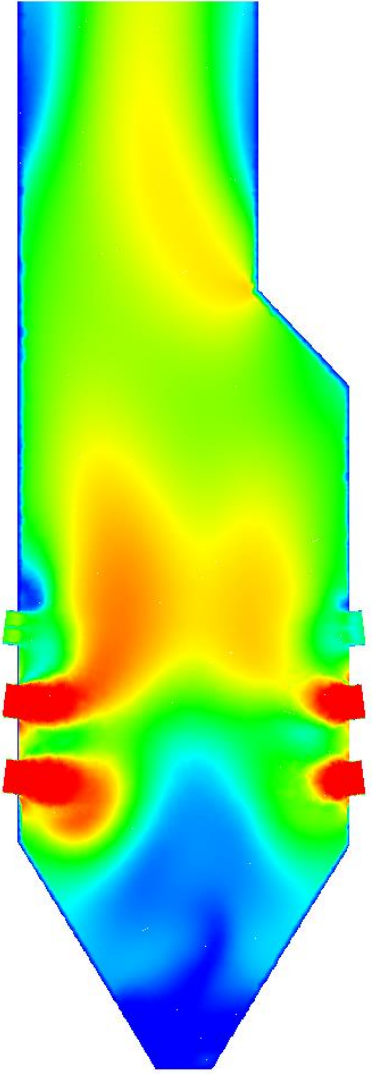

(a)

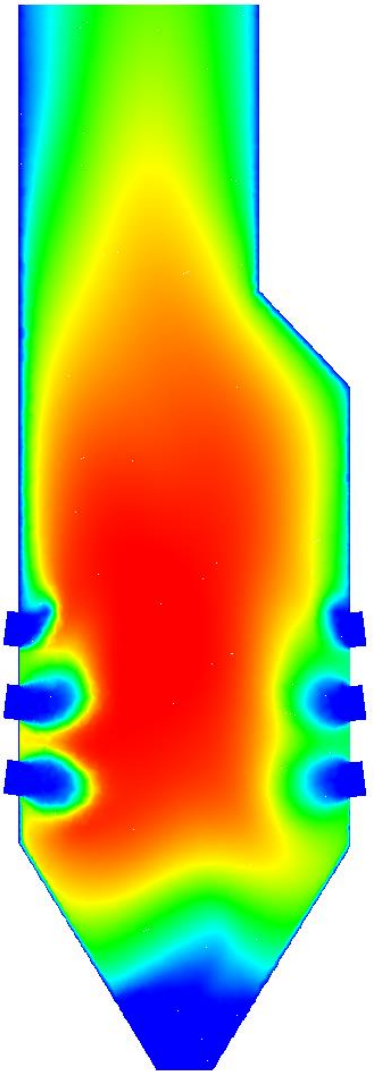

(b)

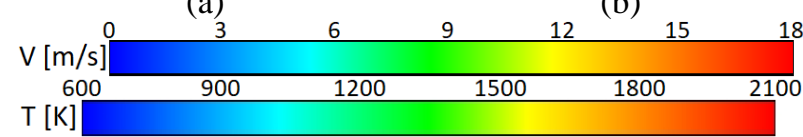

Figure 9. Biomass co-firing - Predicted fields in the furnace in the longitudinal middle plane through the frontal burners, (a) velocity magnitude, (b) static temperature.

It can be observed, again, that the resulting velocity and temperature distributions for the biomass co-firing are (Figure 9) very similar to those of the coal combustion (Figure 6).

One can also see the flame (the high tempeature zone) is slightly shorter for the biomass co-firing (Figure 9b) compared to coal combustion (Figure 6b). This may be attributed to the high volatile content of the biomass that can burn, in the gas phase, more rapidly compared to solid char.

In addition to the comparison based on the contour plots (Figures 5, 6, 8, 9), a quantitative comparison is provided in Table 9, which presents the area averaged values of the predicted velocity magnitude, temperature and $\mathrm{H}_{2} \mathrm{O}, \mathrm{CO}$ and $\mathrm{CO}_{2}$ mole fractions at three burner levels for coal and biomass co-firings. The percentage deviation of the biomass co-firing values from those of coal are also provided in the table (the difference is normalized by the value for coal).

One can see that the velocity and temperature values predicted for both types of firing are, in general, quite close to each other, which was also implied by the comparison of the contour plots.
Table 9. Area averaged velocity magnitude, temperature and species mole fractions predicted for coal and biomass co-firing and their percentage deviation (the latter is calculated on the basis of coal firing and given in absolute value).

\begin{tabular}{|c|c|c|c|}
\hline & $\begin{array}{l}\text { Coal } \\
\text { firing }\end{array}$ & $\begin{array}{l}\text { Biomass } \\
\text { co-firing }\end{array}$ & $\begin{array}{c}\% \\
\text { deviation }\end{array}$ \\
\hline & \multicolumn{3}{|c|}{ Lower Burner Level (L) } \\
\hline $\mathrm{V}_{\text {aver }}[\mathrm{m} / \mathrm{s}]$ & 10.50 & 10.46 & 0.4 \\
\hline $\mathrm{T}_{\text {aver }}[\mathrm{K}]$ & 1525 & 1472 & 3.5 \\
\hline $\mathrm{X}_{\mathrm{H} 2 \mathrm{O}, \text { aver }}[-]$ & 0.057 & 0.068 & 19.3 \\
\hline $\mathrm{X}_{\mathrm{CO}, \text { aver }}[-]$ & 0.0046 & 0.0042 & 8.7 \\
\hline \multirow[t]{2}{*}{$\mathrm{X}_{\mathrm{CO} 2, \text { aver }}[-]$} & 0.114 & 0.1 & 12.3 \\
\hline & \multicolumn{3}{|c|}{ Middle Burner Level (M) } \\
\hline $\mathrm{V}_{\mathrm{aver}}[\mathrm{m} / \mathrm{s}]$ & 11.70 & 11.72 & 0.2 \\
\hline $\mathrm{T}_{\text {aver }}[\mathrm{K}]$ & 1464 & 1432 & 2.2 \\
\hline $\mathrm{X}_{\mathrm{H} 2 \mathrm{O}, \text { aver }}[-]$ & 0.049 & 0.056 & 14.3 \\
\hline $\mathrm{X}_{\mathrm{CO}, \text { aver }}[-]$ & 0.0038 & 0.0038 & 0 \\
\hline \multirow[t]{2}{*}{$\mathrm{X}_{\mathrm{CO} 2 \text {,aver }[-]}$} & 0.102 & 0.0918 & 10.0 \\
\hline & \multicolumn{3}{|c|}{ Upper Burner Level (U) } \\
\hline $\mathrm{V}_{\text {aver }}[\mathrm{m} / \mathrm{s}]$ & 9.70 & 9.69 & 0.1 \\
\hline $\mathrm{T}_{\text {aver }}[\mathrm{K}]$ & 1627 & 1600 & 1.7 \\
\hline $\mathrm{X}_{\mathrm{H} 2 \mathrm{O}, \text { aver }}[-]$ & 0.057 & 0.063 & 10.5 \\
\hline $\mathrm{X}_{\mathrm{CO}, \text { aver }}[-]$ & 0.0043 & 0.0041 & 4.7 \\
\hline $\mathrm{X}_{\mathrm{CO} 2, \mathrm{aver}[-]}$ & 0.1226 & 0.112 & 8.7 \\
\hline
\end{tabular}

The deviations are comparably larger for the species mole fractions (Table 9), due to the differences in the fuel compositions. Biomass has a lower carbon and a higher hydrogen content compared to coal (Tables 7, 8). Consequently, water vapor and carbon monoxide/dioxide mole fractions for biomass co-firing result in higher and lower values compared to coal firing, respectively.

Additionally, one can also observe that the deviations between the two firings, in general, are at largest for the low burner level, and gradually decrease at the middle and the upper burner levels (Table 9). This is an expected trend, since biomass is fired at the low burner level.

Obviously, from the viewpoint of conserving the primary energy resources, biomass has the advantage of being a renewable energy resource. From the environmental point of view, as already mentioned above, an additional advantage of biomass is, that its combustion causes smaller amounts of carbon dioxide emissions, compared to coal, simply due to its comparably lower content on carbon (Tables 7,8 ).

For the present situation, this is demonstrated in Figure 10 , where the predicted carbon dioxide mole fractions at the exit of the furnace (mass averaged values) are compared for coal combustion and biomass co-firing.

A reduction of the carbon dioxide emissions with approximately $10 \%$ by the biomass co-firing can be observed (Figure 10). 


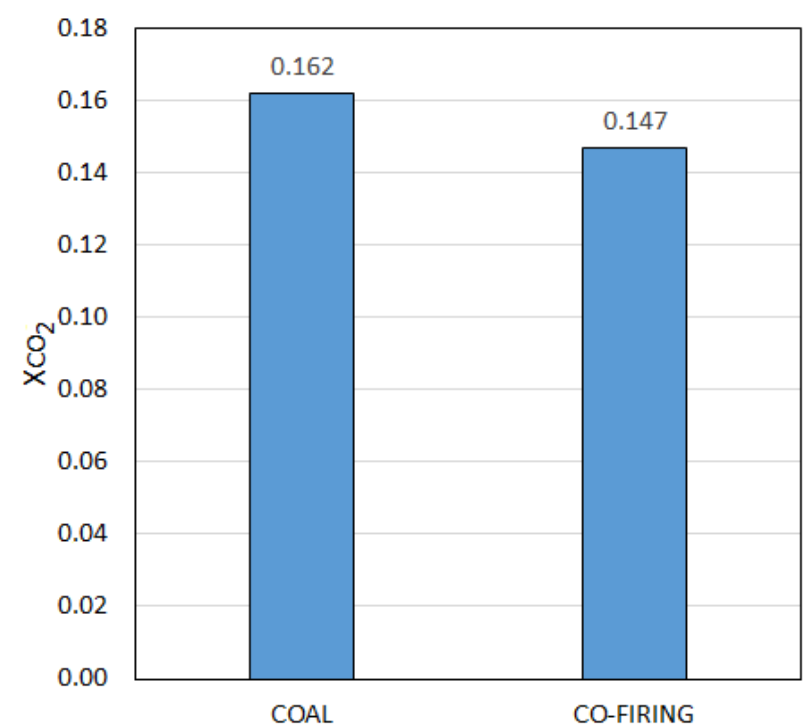

Figure 10. Predicted mean carbon dioxide mole fractions at furnace exit.

\section{CONCLUSIONS}

Within a preliminary feasibility study, pulverized coal and biomass co-firing in the 150MWe unit of Tuncbilek power plant is computationally investigated.

Turkish red pine is assumed to be the biomass source. The eighteen burners of the furnace were arranged at three levels, having six burners at each level. In the assumed co-firing scenario, the burners of the lowest level that supply $43 \%$ of the total fuel mass are fed by biomass, instead of coal. In replacing the coal by biomass, the mass flow rates of the biomass and the corresponding air are adjusted in such a way that the thermal load and the equivalence ratio remain unaltered. The results show that the biomass co-firing results in a very similar flame structure compared to the coal firing. This is encouraging for the application of biomass cofiring in the considered furnace.

For more accurate results and more precise conclusions, further studies are necessary. In the present modelling, there are several sources uncertainty including e.g. the rate constants for the pyrolysis and chemical conversion of biomass being identical to those of coal. Model improvements along these lines will be considered in the future work.

\section{ACKNOWLEDGEMENT}

Computing resources used in this work were provided by the National Center for High Performance Computing of Turkey (UHeM) under grant number 1007492020.

\section{REFERENCES}

Acikkalp, E., Zeng, T., Ortwein, A., Burkhardt, H. and Klenk W., 2018, Exergy, Exergoeconomic and Enviroeconomic Evaluation in a Biomass-Steam Engine Micro-CHP System, Chemical Engineering and Technology, 41(11), 2141-2149.

ANSYS Fluent Theory Guide, 2019, Release 2019 R3, ANSYS Inc., Canonsburg.

Atimtay, A. T., Kayahan, U., Unlu, A., Engin, B., Varol, M., Olgun, H. and Atakul, H., 2017, Co-firing of Pine Chips with Turkish Lignites in $750 \mathrm{kWth}$ Circulating Fluidized Bed Combustion System, Bioresource Technology, 224, 601-610.

Aydin, Ö., 2013, Tunçbilek Termik Santralinde Kömür Kazan Uyumunun Araştırılması, TÜBITAK Araştırma Projesi Gelişme Raporu, Proje No. 112M871.

Aydin, Ö. and Durak, M. M., 2012, The Effect of Temperature Distribution on Tube Rupture, Journal of Thermal Science and Technology, 7(4), 753-766.

Badzioch, S. and Hawskley, 1970, Kinetics of Thermal Decomposition of Pulverized Coal Particles, Industrial \& Engineering Chemistry Process Design and Development, 9, 521-530.

Baum, M. M. and Street, P.J., 1971, Predicting the Combustion Behaviour of Coal Particles, Combustion Science and Technology, 3, 231-243.

Benim, A. C., 1988, A Finite Element Solution of Radiative Heat Transfer in Participating Media Utilizing the Moment Method, Computer Methods in Applied Mechanics and Engineering, 67(1), 1-14.

Benim, A. C., 1990, Finite Element Analysis of Confined Turbulent Swirling Flows, International Journal for Numerical Methods in Fluids, 11, 697-717.

Benim, A. C., Epple, B. and Krohmer, B., 2005, Modelling of Pulverised Coal Combustion by a Eulerian-Eulerian Two-Phase Flow Formulation, Progress in Computational Fluid Dynamics - An International Journal, 5(6), 345-361.

Benim, A. C., Iqbal. S., Meier, W., Joos, F. and Wiedermann, A., 2017, Numerical Investigation of Turbulent Swirling Flames with Validation in a Gas Turbine Model Combustor, Applied Thermal Engineering, 110, 202-212.

Benim, A. C. and Kuppa, K., 2016, Modeling of Entrained-Flow Coal Gasification by an EulerianEulerian Two-Phase Flow Formulation, Isi Bilimi ve Teknigi Dergisi / Journal of Thermal Science and Technology, 36(2), 93-102. 
Benim, A. C., Stegelitz, P. and Epple, B., 2005, Simulation of the Two-Phase Flow in a Laboratory Coal Pulveriser, Forschung im Ingenieurwesen Engineering Research, 69, 197-204.

Bhattacharyya, S., Chattopadhyay, H. and Benim, A. C., 2017, Computational Investigation of Heat Transfer Enhancement by Alternating Inclined Ribs in Tubular Heat Exchanger, Progress in Computational Fluid Dynamics - An International Journal, 17(6), 390-396.

Bhuiyan, A. A. and Naser, J., 2015a, Numerical Modeling of Biomass Co-Combustion with Pulverized Coal in a Small Scale Furnace, Procedia Engineering, $105,504-511$.

Bhuiyan, A. A. and Naser, J., 2015b, CFD Modelling of Co-Firing of Biomass with Coal under Oxy-Fuel Combustion in a Large Scale Power Plant, Fuel, 159, $150-168$

Dryer, F. L. and Glassmann, L., 1973, High Temperature Oxidation of $\mathrm{CO}$ and $\mathrm{CH}_{4}$, Proceedings of the $14^{\text {th }}$ Symposium (Int.) on Combustion, The Combustion Institute, Pittsburgh.

DuBois, E. and Mercier A. (Eds.), 2009, Energy Recovery, Nova Science Publishers, New York.

Ebling, D. G., Krumm, A., Pfeiffelmann, B., Gottschald, J., Bruchmann, J., Benim, A. C., M. Adam, M., Labs, R., Herbertz, R. R. and Stunz, A., 2016, Development of a System for Thermoelectric Heat Recovery from Stationary Industrial Processes, Journal of Electronic Materials, 45(7), 3433-3439.

Ehrlich, R., 2013, Renewable Energy, CRC Press, Boca Raton.

Epple. B., Leithner, R., Linzer, W. and Walter H. (Eds.), 2012, Simulation von Kraftwerken und Feuerungen, Springer, Vienna.

Field, M. A., Gill, D. W., Morgan, B. B. and Hawskley, 1967, Combustion of Pulverized Coal, The British Coal Utilization Research Association, Letherhead.

Gosman A. D. and Ioannides, E., 1983, Aspects of Computer Simulation of Liquid-Fuelled Combustors, Journal of Energy, 7(6), 482-490.

Hein, K. R. G. and Spliethoff, 1995, Co-combustion of Coal and Biomass in Pulverized Fuel and Fluidized Bed Systems, The Institute of Energy's Second International Conference on Combustion \& Emissions Control, 127136.

Heinzel, T., Siegle, V., Spliethoff H. and Hein, K. R. G., 1998, Investigation of Slagging in Pulverized Fuel CoCombustion of Biomass and Coal at a Pilot-Scale Test Facility, Fuel Processing Technology, 54 (1-3),109-125.
Kaltschmitt, M. (Ed.), 2019, Energy from Organic Materials, Springer, New York.

Kaltschmitt, M., Hartmann, H. and Hofbauer, H. (Eds), 2016, Energie aus Biomasse, $3^{\text {rd }}$ ed., Springer, Berlin.

Kim, J. P., Schnell, U., Scheffknecht, G., and Benim, A. C., 2007, Numerical Modelling of MILD Combustion for Coal, Progress in Computational Fluid Dynamics An International Journal, 7(6), 337-346.

Launder, B. E. and Spalding, D. B., 1974, The Numerical Computation of Turbulent Flows, Computer Methods in Applied Mechanics and Engineering, 3(2), 269-289.

Lefebvre, A. H. and McDonnel, V. G., 2017, Atomization and Sprays, $2^{\text {nd }}$ ed., CRC Press, Boca Raton.

Libby, P. A. and Williams. F. A., 1994, Turbulent Reacting Flows, Academic Press, Cambridge.

Madjeski, P., 2018, Coal Combustion Modelling in a Frontal Pulverized Coal-Fired Boiler, E3S Web of Conferences, 46, 00010.

Magnussen, B. F. and B. H. Hjertager, 1976, On Mathematical Modelling of Turbulent Combustion with Special Emphasis on Soot Formation and Combustion, Proceedings of the $16^{\text {th }}$ Symposium (Int.) on Combustion, The Combustion Institute, Pittsburgh, 719729.

Menter, F. R., 1994, Two-Equation Eddy-Viscosity Turbulence Models for Engineering Applications, AIAA Journal, 32(8), 1598-1605.

Morsi, S. A. and Alexander, A. J., 2006, An Investigation of Particle Trajectories in Two-Phase Flow Systems, Journal of Fluid Mechanics, 55(2), 193-208.

Munir, S., Nimmo, W. and Gibbs, B. M., 2011. The Effect of Air-Staged, Co-Combustion of Pulverised Coal and Biomass Blends on $\mathrm{NO}_{\mathrm{x}}$ Emissions and Combustion Efficiency, Fuel, 90, 126-135.

Neves, D., Thunman, H., Matos, A., Tarelho, L. and Gomez-Barea, A., 2011, Progress in Energy and Combustion Science, 27, 611-630.

Nimmo, W., Daood, S. S. and Gibbs, B. M., 2010, The Effect of $\mathrm{O}_{2}$ Enrichment on $\mathrm{NO}_{\mathrm{x}}$ Formation in Biomass Co-Fired Pulverised Coal Combustion, Fuel, 89, 29452952.

Ozdemir, F. and Boke. E., 2015, Tunçbilek Termik Santrali 5 Ünite Kazanının Sayısal Modellemesi, 13. Uluslararası Yanma Sempozyumu, Bursa, 9 Eylül 2015. 
Pérez-Jeldres, R., Cornejo, P., Flores, M., Gordon, A. and Garcia.X., 2017, A Modeling Approach to CoFiring Biomass/Coal Blends in Pulverized Coal Utility Boilers: Synergetistic Effects and Emissions Profiles, Energy, 120, 663-674.

Ranz W. E. and Marshall, Jr. W. R., 1952, Evaporation from Drops, Part I and Part II, Chemical Engineering Progress, 48(4), 173-180.

Shi, X., Gao, J. and Lan, X., 2019, Modelling the Pyrolysis if a Centimeter-Sized Biomass Particle, Chemical Engineering Technology, 2019, 42(12), 25742579 .

Smith, J. D., Alembath, A., Al-Rubaye, H., Yu, J., Gao, X. and Golpour, H., 2019, Validation and Application of a Kinetic Model for Downdraft Biomass Gasification Simulation, Chemical Engineering and Technology, 42(12), 2505-2519.

Smith, T. F., Shen, Z. F. and Friedman, J. N., 1982, Evaluation of Coefficients for the Weighted Sum of Gray Gases Model, Journal of Heat Transfer, 104, 602608.

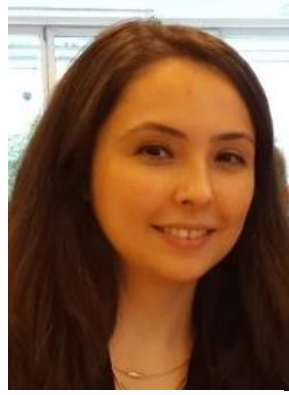

Cansu Deniz Canal, M.Sc., graduated from Marmara University, Environmental Engineering and Mechanical Engineering Department of Engineering Faculty in 2011. She earned her MSc. degree at İstanbul Technical University, Energy Science and Technology Department in 2014. She is working as a research assistant at Istanbul Technical University, Mechanical Engineering Faculty since 2014. She worked as a guest researcher at Heat and Mass Transfer Institute of RWTH Aachen University and Center of Flow Simulation of Düsseldorf University of Applied Sciences. She is currently working on her $\mathrm{PhD}$. Thesis, which is related to pulverized coal and biomass co-firing. Her research topics are combustion, hydrogen production technologies and renewable energy systems.

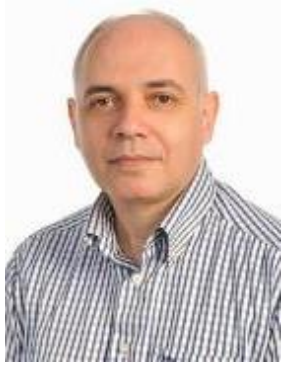

Prof. Dr. Yakup Erhan Boke graduated from Yıldız Technical University, Faculty of Mechanical Engineering in 1983. His MSc. study was completed at İstanbul Technical University, Mechanical Engineering Department in 1985, and PhD was finished at the same university in 1993. He worked as a guest researcher at Clausthal Technical University between 1990 and 1992, as a research assistant between 1984 and 1994 at İstanbul Technical University and as Assist. Prof. Dr. between 1994-2013. Between 2013-2018, he was Assoc. Prof. Dr. at the same university. Now, he is working as Prof. Dr. at İstanbul Technical University, Mechanical Engineering Faculty. His research topics are combustion, steam boilers, CFD and heat technology.

Prof. Dr. Ozer Aydin completed his BSc. degree at Kutahya Dumlupınar University,

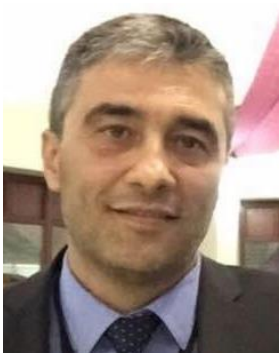

Mechanical Engineering Department. He received his MSc. and PhD degrees in 1999 and 2005, respectively, from Eskisehir Osmangazi University, Mechanical Engineering Department. He worked as a research assistant between 1997 and 2003 at Kutahya Dumlupinar University and as Assist. Prof. Dr. between 2006-2014. Between 2014-2019, he was Assoc. Prof. Dr. at the same university. He is working at Kütahya Dumlupınar University, Mechanical Engineering Department as a Prof. Dr. since 2006. His research topics are combustion, emission control technologies and internal combustion engines. 


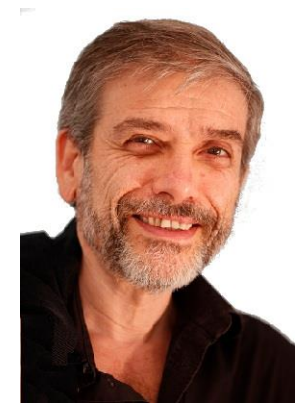

Prof. Dr.-Ing. Ali Cemal Benim received his B.Sc. and M.Sc. degrees in Mechanical Engineering at the Boğaziçi University, Istanbul, Turkey. He received his Ph.D. degree at the University of Stuttgart, Germany, in 1988, on the topic "Finite Element Modeling of Turbulent Diffusion Flames" with "Degree of Distinction". Following a post-doctoral period at the University of Stuttgart, in 1990 he joined ABB Turbo Systems Ltd. in Baden, Switzerland, where he was the manager of the "Computational Flow and Combustion Modeling" group. Since January 1996, he is Professor for Energy Technology and Head of Center of Flow Simulation at the Duesseldorf University of Applied Sciences, Duesseldorf, Germany. 